\title{
Adenoma of pancreas
}

INSERM

\section{Source}

INSERM. (1999). Orphanet: an online rare disease and orphan drug data base. Adenoma of pancreas. ORPHA:93292

Adenoma of the pancreas is a rare, benign, tumor of the pancreas characterized by variable number and size of the cysts lined with glycogen rich epithelial cells. Clinical manifestation may include epig astric or abdominal pain, weight loss, diabetes, jaundice and palpable abdominal mass. Some patients have no symptoms and the tumor is discovered incidentally. 